\title{
AKIBAT HUKUM PUTUSAN PAILIT TERHADAP KREDITOR PREFEREN DALAM PERJANJIAN KREDIT YANG DIJAMINKAN DENGAN HAK TANGGUNGAN
}

\author{
Danik Gatot Kuswardani ${ }^{1}$, Achmad Busro ${ }^{2}$
}

\begin{abstract}
Abstrak
Pokok permasalahan yaitu: (1) Bagaimana hambatan pelaksanaan eksekusi hak tanggungan apabila debitur dinyatakan pailit. (2) Bagaimanakah akibat hukum dan kedudukan kreditor preferen pemegang hak tanggungan apabila Debitor dinyatakan pailit. Metode Penelitian yang digunakan adalah metode pendekatan yuridis normatif, yaitu penelitian yang didasarkan pada data sekunder. Spesifikasi penelitian yang digunakan deskriptif analitis.Sumber data yang digunakan terdiri dari bahan hukum primer dan bahan hukum sekunder. Hasil penelitianditemukan bahwa: 1. Hambatan dalam Pelaksanaan eksekusi hak tanggungan dalam hal debitor dinyatakan pailit, antara lain adalah: (a) Debitor pailit tidak kooperatif; (b) Debitor beritikad buruk; (c) Kurangnya tenggang waktu bagi kreditor Pemegang hak tanggungan; (d) sering terjadi persekongkolan antara debitor yang beritikad buruk dengan kurator; (e) Ketidakprofesionalnya kurator dalam mengurus harta-harta debitor yang telah dinyatakan pailit. 2. Akibat hukum putusan pailit bagi kreditor preferen pemegang hak tanggungan apabila debitor dinyatakan pailit adalah tetap dapat menjalankan haknya sebagai kreditor separatis, seolah -olah tidak terjadi kepailitan, sebagaimana yang diatur dalam Pasal 55 ayat (1 ) Undang-Undang Kepailitan dan Penundaan Kewajiban Pembayaran Utang.
\end{abstract}

Kata Kunci: Hak Tanggungan, Kepailitan, Pembayaran Utang

\footnotetext{
${ }^{1}$ Mahasiswa Program Studi Magister Ilmu Hukum UNDIP

${ }^{2}$ Dosen Program Studi Magister Ilmu Hukum UNDIP
} 


\section{A. PENDAHULUAN}

\section{Latar Belakang}

Kepailitan dan penundaan pembayaran utang diatur dalam undang-undang Nomor 37 Tahun 2004. Melalui kepailitan dan penundaan kewajiban pembayaran utang diharapkan menjamin keamanan dan menjamin kepentingan para pihak yang bersangkutan. Hal itu disebabkan melalui kedua lembaga hukum tersebut akan terlibat instansi dan personel yang mengemban tugas resmi dari pemerintah. Instansi atau lembaga dimaksud misalnya Pengadilan Niaga, Hakim Pengawas, dan Kurator. Hak dan kewajiban, tugas dan wewenang instansi dan personil yang terlibat dalam penyelesaian utang piutang melalui penundaan kewajiban pembayaran utang dan kepailitan yang bersangkutan. $^{3}$

Berdasarkan Pasal 2 ayat 1 Undang-Undang Kepailitan, syarat-syarat pengajuan permohonan pernyataan pailit adalah:Syarat adanya dua kreditor atau lebih, Syarat harus adanya utang, Syarat cukup satu utang yang telah jatuh waktu dan dapat ditagih.

Kepailitan mengakibatkan debitor kehilangan haknya dalam lapangan hukum harta kekayaannya karena seluruh harta kekayaan debitor serta segala sesuatu yang diperoleh selama kepailitan berada dalam sitaan umum sejak saat putusan pernyataan pailit diucapkan sebagaimana yang diatur dalam Undang-Undang Kepailitan Bagian Kedua tentang Akibat Kepailitan.

Putusan Pailit juga berakibat secara khusus terhadap hak jaminan dan hak istimewa, antara lain adalah hipotek, gadai, hak tangggungan dan fidusia sebagaimana yang diatur dalam Pasal 55 Undang-Undang Kepailitan. Hak tanggungan sebagai salah satu hak jaminan diatur dalam Undang-Undang Hak Tanggungan yaitu Undang-Undang Nomor.4 Tahun 1996 tentang Hak Tanggungan Atas Tanah Beserta Benda-Benda yang berkaitan dengan Tanah. Prosedur pelaksanaan Hak Tanggungan hingga proses eksekusi Hak Tanggungan telah diatur dalam Undang-Undang Hak Tanggungan. Menurut Undang-Undang Nomor 4 Tahun 1996 Pasal 1 ayat (1):

\footnotetext{
${ }^{3}$ Man S.Sastrawidjaja, Hukum Kepailitan dan Penundaan Kewajiban Pembayaran Utang, Bandung:PT.Alumni , 2006, hlm. 2-3.
} 
"Hak Tanggungan adalah hak jaminan yang dibebankan pada hak atas tanah sebagaimana dimaksud dalam Undang-Undang Nomor 5 Tahun 1960 tentang Peraturan Dasar Pokok-Pokok Agraria, berikut atau tidak berikut benda-benda lain yang merupakansatu kesatuan dengan tanah itu, untuk pelunasan utang tertentu, yang memberikan kedudukan yang diutamakan kepada kreditor tertentu terhadap kreditor-kreditor lain".

Perjanjian kredit yang dijaminkan dengan Hak Tanggungan, apabila debitor cidera janji atau wanprestasi maka eksekusi dilakukan melalui gugatan perdata ke Pengadilan Negeri, atau melakukan eksekusi berdasarkan Pasal 20 UUHT, yaitu dijual melalui pelelangan umum berdasarkan title eksekutorial yang terdapat dalam Sertipikat Hak Tanggungan ( Pasal 20 ayat (1) UUHT ), dan penjualan dibawah tangan sebagaimana diatur dalam Pasal 20 ayat (2) dan (3) UUHT.

Putusan pailit pada debitor, mempengaruhi kedudukan kreditor pemegang hak tanggungan dalam proses eksekusi untuk memperoleh pelunasan piutangnya. Pasal 1 dan Pasal 20 UUHT memberikan kedudukan yang diutamakan bagi kreditor pemegang hak tanggungan ( hak preferen ). Pasal 6 dan Pasal 20 UUHT mengatur mengenai pelaksanaan eksekusi objek Hak Tanggungan yang dapat dilakukan dengan cara parate eksekusi berdasarkan title eksekutorial yang ada di Sertipikat Hak Tanggungan. Kedudukan kreditor pemengang hak Tanggungan juga diatur dalam Undang-Undang Kepailitan Pasal 55 ayat (1), yang menyatakan bahwa Kepailitan tidak mempunyai pengaruh apapun terhadap Hak Hak Tanggungan dan kreditor diberi kewenangan untuk mengeksekusi haknya seolah-olah tidak terjadi kepailitan. Kewenangan kreditor untuk melakukan eksekusi terhadap objek Hak Tanggungan pelaksanaannya harus tetap memperhatikan Pasal 56, Pasal 57 dan Pasal 58 Undang-Undang Kepailitan yang mengatur bahwa, sebelum kreditor atau pihak ketiga megeksekusi, harus diperhatikan Pasal 56 ayat (1) Undang-Undang Kepailitan yang menentukan bahwa hak eksekusi kreditor dan pihak ketiga untuk menuntut hartanya yang berada dalam penguasan 
debitor pailit dan kurator, ditangguhkan untuk jangka waktu paling lama 90 hari sejak putusan pernyataan pailit diucapkan.

Akibat Putusan pailit bagi kreditor pemegang hak tanggungan, disatu sisi dikatakan tidak berpengaruh terhadap proses eksekusi objek hak tanggungan yang dilakukan kreditor, akan tetapi hal tersebut juga terhambat karena Pasal 56 ayat (1) Undang-Undang Kepailitan yang mengatur mengenai penangguhan terhadap eksekusi agunan yang berada dalam penguasan debitor pailit atau kurator, selama 90 hari terhitung sejak putusan pailit dibacakan. Selama berlangsungnya jangka waktu penangguhan, segala tuntutan hukum untuk memperoleh pelunasan atas suatu piutang tidak dapat diajukan dalam sidang peradilan, baik kreditor maupun pihak ketiga dilarang mengeksekusi ataupun memohonkan sita atas benda yang menjadi agunan.

\section{Rumusan Masalah.}

Berdasarkan latar belakang yang telah diuraikan diatas, maka dapat dirumuskan permasalahan sebagai berikut:

1. Bagaimana hambatan pelaksanaan eksekusi hak tanggungan apabila debitor dinyatakan pailit?

2. Bagaimana akibat hukum dan kedudukan kreditor preferen pemegang hak tanggungan apabila debitor dinyatakan pailit?

\section{Tinjauan Pustaka}

Kepailitan adalah sita umum atas semua kekayaaan debitor pailit yang pengurusan dan pemberesannya dilakukan oleh kurator dibawah pengawasan Hakim Pengawas sebagaimana diatur dalam Undang-Undang No.37 Tahun 2004 Pasal 1 ayat (1).

Tujuan pernyataan pailit sebenarnya adalah untuk mendapatkan suatu penyitaan umum atas kekayaan debitor ( segala harta benda disita/dibekukan ) untuk kepentingan semua orang yang menghutangkannya ( kreditor ). Prinsipnya kepailitan itu adalah suatu 
usaha bersama untuk mendapatkan pembayaran bagi semua orang berpiutang secara adil. ${ }^{4}$

Proses Kepailitan berdasarkan Undang-Undang No. 37 Tahun 2004 diatur dalam Pasal 6 s/d Pasal 11, yaitu:

a) Tahap Pendaftaran Permohonan Pernyataan Pailit. Pemohon mengajukan permohonan pernyataan pailit kepada Ketua Pengadilan Niaga. Panitera Pengadilan Niaga wajib mendaftarkan permohonan tersebut pada tanggal permohonan yang bersangkutan diajukan dan kepada pemohon diberikan tanda terima tertulis yang ditandatangani oleh pejabat yang berwenang dengan tanggal yang sama dengan tanggal pendaftaran. Setelah mendaftarakan permohonan pernyataan pailit, panitera menyampaikan permohonan tersebut kepada Ketua Pengadilan Niaga paling lambat 2 (dua) hari setelah permohonan didaftarkan. ${ }^{5}$ Sebelum persidangan dimulai, pengadilan melalui juru sita melakukan pemanggilan para pihak , antara lain: ${ }^{6}$

1) Wajib memanggil Debitor, dalam hal permohonan pernyataan pilit diajukan oleh Kreditor, Kejaksaan, Bank Indonesia, Bapepam, atau Menteri Keuangan.

2) Dapat memanggil kreditor dalam hal permohonan pernyataan pailit diajukan oleh debitor ( voluntary petition ) dan terdapat keraguan bahwa persyaratan untuk dinyatakan pailit sebagaimana dimaksud dalam Pasal 2 ayat (1) Undang-Undang Kepailitan telah terpenuhi.

b) Pemanggilan dilakukan oleh juru sita dengan surat kilat tercatat paling lambat 7 hari sebelum sidang pemeriksaan pertama diselenggarakan. Dalam jangka waktu paling lambat 3 hari setelah tanggal permohonan pernyataan pailit didaftarkan, pengadilan mempelajari permohonan dan menetapkan sidang. Sidang pertama pemeriksaan atas permohonan pernyataan pailit diselenggarakan dalam jangka waktu paling lambat 20 (dua puluh) hari setelah tanggal permohonan didaftarkan. Menurut

${ }^{4}$ Ibid, hlm 124

${ }^{5}$ Jono, Op.Cit, hlm.89.

${ }^{6}$ Loc.Cit. 
Pasal 6 ayat (7) UUK, Pengadilan dapat menunda penyelenggaraan sidang tersebut sampai dengan paling lambat 25 (dua puluh lima) hari setelah tanggal permohonan didaftarkan. Penundaan ini atas

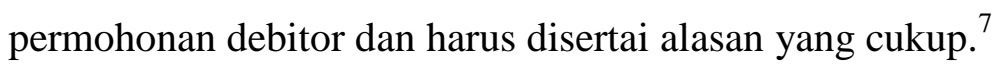

c) Dalam Pasal 10 ayat (1) Undang-Undang Kepailitan dinyatakan bahwa selama putusan atas permohonan pernyataan pailit belum diucapkan , setiap kreditor, kejaksaan, Bank Indonesia , Bapepam , atau Menteri Keuangan dapat mengajukan permohonan kepada pengadilan untuk: ${ }^{8}$

1) Meletakkan sita jaminan terhadap sebagian atau seluruh kekayaan debitor, atau

2) Menunjuk Kurator sementara untuk mengawasi Pengelolaan usaha debitor, dan Pembayaran kepada kreditor, pengalihan, atau pengagunan kekayaan debitor yang dalam kepailitan merupakan wewenang kurator.

d) Pengadilan hanya dapat mengabulkan permohonan tersebut apabila hal tersebut diperlukan guna melindungi kepentingan kreditor sebagaimana diatur dalam Pasal 10 ayat (2) Undang-Undang Kepailitan. Putusan Pengadilan Niaga atas permohonan pernyataan pailit harus diucapkan paling lambat 60 ( enam puluh ) hari setelah tanggal permohonan pernyataan pailit didaftarkan. ${ }^{9}$

Akibat dari dijatuhkannya paillit adalah: ${ }^{10}$

a) Debitor kehilangan segala haknya untuk menguasai dan mengurus atas harta kekayaan harta bendanya ( asetnya ), baik menjual, menggadai, dan lain sebagainya serta segala sesuatu yang diperoleh selama kepailitan sejak tanggal putusan pernyataan pailit diucapkan.

b) Utang-utang baru tidak lagi dijamin oleh kekayaannya;

c) Untuk melindungi kepentingan kreditor, selama putusan atas permohonan pernyataan pailit belum diucapkan, kreditor dapat mengajukan permohonan kepada pengadilan untuk:

\footnotetext{
${ }^{7}$ Loc.Cit

${ }^{8}$ Ibid, Hal.90

${ }^{9}$ Ibid, Hal.91

${ }^{10}$ Abdul R. Saliman, Op.Cit, Hal. 124-125
} 
1) Meletakkan sita jaminan terhadap sebagian atau seluruh kekayaan debitor.

2) Menunjuk kurator sementara untuk mengawasi pengelolaan usaha debitor, menerima pembayaran kepada kreditor, pengalihan atau penggunaan kekayaan debitor ( Pasal 10 Undang-Undang No.37 Tahun 2004 ).

d) Harus diumumkan dua kali surat kabar ( Pasal 15 ayat (4) UndangUndang No.37 Tahun 2004 ).

e) Putusan pernyataan pailit mengakibatkan harta kekayaan debitor dimasukkan dalam harta pailit sejak putusan tersebut dikeluarkan. Undang undang kepailitan tidak memberi ketentuan yang eksplisit mengenai berubahnya status harta debitor menjadi harta pailit setelah adanya putusan pernyataan pailit. Hal itu hanya tersirat dari ketentuan-ketentuan dalam undang-undang kepailitan. Istilah harta pailit dipakai dalam berbagai pasal undang-undang kepailitan (Sutan Reny Syahdeini, 2002:197). Kepailitan meliputi seluruh kekayaan debitor pada saat putusan pernyataan pailit diucapkan serta segala sesuatu yang diperoleh selama kepailitan (Pasal 21 UU Nomor 37 Tahun 2004). Ada dua macam harta debitor yang tidak termasuk harta pailit. Harta tersebut adalah harta debitor yang dimaksudkan dalam Pasal 21 UU Nomor 37 Tahun 2004 dan harta bukan milik debitor. ${ }^{11}$

f) Pengurusan harta pailit dilakukan oleh kurator yang ditetapkan dalam putusan pernyataan pailit tersebut. Pelaksanaan pengurusan harta pailit oleh kurator bersifat seketika, berlaku saat itu juga terhitung sejak putusan pailit diucapkan. ${ }^{12}$

Kreditor separatis ( kreditor pemegang hak kebendaan seperti kreditor pemegang hak tanggungan ) atau pihak ketiga berdasarkan Pasal 137 ayat (2) Undang-Undang Kepailitan dapat mengeksekusi haknya seolah-olah tidak terjadi kepailitan, akan tetapai sebelum kreditor atau pihak ketiga

\footnotetext{
${ }^{11}$ Munir Fuady, Hukum Pailit, Bandung:PT. Citra Aditya Bakti, 2005, hlm. 148-149.

${ }^{12}$ Ahmad Yani dan Gunawan Widjaja, Kepailitan, Jakarta:PT. Raja Grafindo Persada,1999, hlm.62.
} 
tersebut mengeksekusi, harus diperhatikan Pasal 56 ayat (1) UndangUndang Kepailitan yang menentukan bahwa hak eksekusi kreditor dan pihak ketiga untuk menuntut hartanya yang berada dalam penguasaan debitor pailit atau kurator, ditangguhkan untuk jangka waktu paling lama 90 hari sejak tanggal putusan pernyataan pailit diucapkan.

\section{Metode Penelitian}

metode yang digunakan dalam penelitian ini adalah pendekatan yuridis normatif $^{13}$. Spesifikasi penelitian yang digunakan bersifat deskriptif analisis, yaitu metode penelitian dengan cara mengumpulkan data-data sesuai dengan data yang sebenarnya kemudian data-data tersebut disusun, diolah dan dianalisis untuk dapat memberikan gambaran mengenai masalah yang ada. ${ }^{14}$ Data sekunder yang diperoleh akan disajikan dalam bentuk uraian yang disusun secara sistematis sebagai suatu rangkaian yang utuh.Maka metode yang digunakan dalam penulisan hukum ini adalah metode kualitatif, yaitu data yang diperoleh disusun secara sistematis dalam bentuk uraian atau penjelasan untuk menggambarkan hasil penelitian. $^{15}$

\section{B. ANALISA DAN PEMBAHASAN}

\section{Hambatan Pelaksanaan Eksekusi Hak Tanggungan Apabila Debitor Dinyatakan Pailit.}

Pelaksaaan eksekusi pada objek Hak tanggungan itu sendiri diatur dalam Pasal 6 dan Pasal 20 UUHT. Pasal 6 UUHT mengatur mengenai Parate eksekusi, yang pelaksanaannya tunduk pada Pasal 224 HIR dan Pasal 256 RBG, yaitu memberikan hak kepada Pemegang Hak Tangggungan untuk menjual objek Hak Tanggungan atas kekuasaan sendiri melalui pelelangan umum serta mengambil pelunasan piutang dari hasil penjualan tersebut atas dasar title eksekutorial yang terdapat dalam Sertipikat Hak Tanggungan sebagaimana yang dimaksud dalam

\footnotetext{
${ }^{13}$ Soerjono Soekanto dan Sri Mamudji. Penelitian Hukum Normatif (Suatu Tinjauan Singkat). Jakarta: Rajawali Pers, 2010. hlm 13-14.

${ }^{14}$ Sugiyono, Metode Penelitian Kuantitatif, Kualitatif dan R\&D, Bandung: CV.Alfabeta, 2008, hlm.105

${ }^{15}$ Soerjono Soekanto, Pengantar Penelitian Hukum , Jakarta:UI Press, 1986, hlm.43
} 
Pasal 14 UUHT. Pasal 20 UUHT selain mengatur mengenai parate eksekusi juga mengatur mengenai penjualan dibawah tangan atas dasar kesepakatan antara pemberi hak tanggungan dengan pemegang hak tanggungan.

Kedudukan kreditor pemegang hak tanggungan memiliki kedudukan sebagai kreditor preferen juga diatur dalam Pasal 55 ayat (1) Undang-Undang No.37 Tahun 2004 tentang Kepailitan dan Penundaan Kewajiban Pembayaran Utang, yang berbunyi " Dengan tetap memperhatikan ketentuan sebagaimana dimaksud dalam Pasal 56, Pasal 57, dan Pasal 58, setiap Kreditor pemegang gadai, jaminan fidusia, Hak Tanggungan, hipotik, atau hak agunan atas kebendaan lainnya, dapat mengeksekusi hanya seolah-olah tidak terjadi kepailitan”.

Kreditor Pemegang Hak Tanggungan sebagai kreditor separatis, istilah sparatis yang berkonotasi pemisahan, karena kedudukan kreditor tersebut terpisah dari kreditor lainnya, dalam arti dapat menjual sendiri dan mengambil sendiri dari hasil penjualan yang terpisah dengan harta pailit lainnya. ${ }^{16}$

Berdasarkan Pasal 55 ayat (1) Undang-Undang Kepailitan dan Penundaan Kewajiban Pembayaran Utang, pemegang hak tanggungan berkedudukan sebagai kreditor separatis yang memiliki hak preferen dapat menjual dan mengambil hasil penjualan jaminan utang tersebut, seolah-olah tidak terjadi kepailitan, akan tetapi kreditor pemegang hak Tanggungan harus tetap memperhatikan ketentuan Pasal 56, Pasal 57 dan Pasal 58 Undang-Undang Kepailitan dan Penundaan Kewajiban Pembayaran Utang, yang berarti bahwa kreditor separatis harus tunduk pada aturan yang menyangkut penangguhan eksekusi untuk masa tertentu yaitu maksimum selama 90 ( Sembilan puluh ) hari sejak tanggal putusan pernyataan pailit diucapkan, serta maksimum 270 hari untuk penundaankewajiban pembayaran utang.

Pemegang hak tanggungan tetap memperhatikan ketentuan Pasal 56, Pasal 57, dan Pasal 58, untuk melaksanakan haknya sebagaiamana yang

${ }^{16}$ Munir Fuady, Hukum Pailit Dalam Teori dan Praktek, Bandung:PT.Citra Aditya Bakti , 1999. hlm. 105. 
diatur dalam pasal 55 ayat (1) Undang-Undang Kepailitan dan Penundaan Kewajiban Pembayaran Utang, yaitu harus melaksanakan haknya tersebut dalam jangka waktu paling lambat 2 ( dua ) bulan terhitung sejak dimulainya keadaan insolvensi.

Setelah lewat jangka waktu 2 ( dua ) bulan, kurator harus menuntut diserahkannya barang yang menjadi agunan untuk selanjutnya dijual sesuai dengan cara sebagaimana dimaksudkan Pasal 185 tanpa mengurangi hak kreditor pemegang Hak Tanggungan atas hasil penjualan agunan tersebut berdasarkan Pasal 185 Undang-Undang Kepailitan dan Penundaan Kewajiban pembayaran Utang, mengatur mengenai prosedur lelang.

Beberapa hambatan dalam pelaksanaan eksekusi hak tanggungan dalam hal debitor dinyatakan pailit antara lain adalah: ${ }^{17}$

a. Debitor pailit tidak kooperatif sejak awal dimulainya proses kepailitan seperti sulit dimintai data tentang assetnya, tidak hadir dalam rapat pencocokan piutang, dan sulit untuk ditemui atau tidak bersedia hadir di pengadilan.

b. Debitor beritikad buruk, seperti mengalihkan asset yang menjadi objek hak tanggungan, kepada pihak lain, sebelum dinyatakan pailit.

c. Kurangnya tenggang waktu bagi kreditor Pemegang hak tanggungan untuk melaksanakan hak ekskusi atas objek hak tanggungan. Hal ini karena Waktu 2 ( dua ) bulan setelah keadaan insolvensi, merupakan waktu yang terlalu singkat bagi kreditor pemegang hak tanggungan untuk melaksanakan haknya sebagai kreditor sparatis yang mempunyai hak preferen.

d. Setelah kreditor pemegang hak tanggungan tidak melaksanakan haknya, maka kewenangan berada ditangan kurator, dalam beberapa kasus sering terjadi persekongkolan antara debitor yang beritikad buruk dengan kurator dalam pemberesan harta pailit, meskipun hal ini sulit untuk dibuktikan.

\footnotetext{
${ }^{17}$ Ira Setiawati, wawancara, Hakim Pengadilan Niaga Semarang, Pada Tanggal 14 November 2013.
} 
e. Ketidakprofesionalnya kurator dalam mengurus harta-harta debitor yang telah dinyatakan pailit, khususnya yang berkaitan dengan audit pembukuan.

Dalam proses kepailitan sering ditemui hambatan-hambatan yang menghalangi jalannya proses kepailitan sampai dengan pelaksanaan putusan kepailitannya. Hambatan ini bisa menimbulkan ketidakpastian hukum karena dengan lambatnya pelaksanaan putusan kepailitan maka dapat menimbulkan penyimpangan-penyimpangan dalam pelaksanaan kepailitan tersebut, padahal Undang-undang No.37 tahun 2004 ini menganut asas keseimbangan, asas kelangsungan usaha, asas keadilan, dan asas integrasi. Hambatan-hambatan dalam pelaksanaan eksekusi hak tanggungan dalam hal debitor pailit ini tidak sesuai dengan asas keseimbangan, karena terdapat pihak-pihak yang tidak jujur, khususnya dari pihak debitor kurator.

\section{Akibat Hukum Dan Kedudukan Kreditor Preferen Pemegang Hak} Tanggungan Apabila Debitor Dinyatakan Pailit.

Pernyataan Pailit dilakukan oleh Hakim Pengadilan Niaga dengan suatu putusan yang menimbulkan suatu akibat hukum baru seperti antara lain Debitor yang semula berwenang mengurus dan menguasai hartanya menjadi tidak berwenang mengurus dan menguasai hartanya sebagaimana yang dikemukakan pada Pasal 24 Undang-Undang Kepailitan dan Penundaan Kewajiban Pembayaran Utang, yaitu:

1. Debitor demi hukum kehilangan haknya untuk menguasai dan mengurus kekayaannya yang termasuk dalam harta pailit, sejak tanggal putusan pernyataan pailit dinyatakan.

2. Tanggal putusan sebagaimana dimaksud pada ayat (1) dihitung sejak pukul 00.00 waktu setempat.

3. Dalam hal sebelum putusan pernyataan pailit diucapkan telah dilaksanakan transfer dana melalui bank atau lembaga selain bank pada tanggal putusan sebagaimana dimaksud pada ayat (1), transfer tersebut wajib diteruskan. 
4. Dalam hal sebelum putusan pernyataan pailit diucapkan telah dilaksanakan transaksi efek di bursa efek maka transaksi tersebut wajib diselesaikan.

Akibat kepailitan terhadap barang jaminan, yaitu bahwa setiap kreditor yang memegang hak tanggungan, hak gadai atau hak agunan atas kebendaan lainnya dapat mengeksekusi sendiri haknya seolah-olah tidak terjadi kepailitan. Akibat kepailitan bagi pemegang hak tanggungan sebagaiamana yang diatur dalam Undang-Undang Hak Tanggungan Penjelasan Pasal 21 yang menyatakan bahwa kedudukan diutamakan pemegang hak tanggungan dengan mengecualikan berlakunya akibat kepailitan pemberi hak tanggungan terhadap objek hak tanggungan.

Pasal 55 Undang-Undang Kepailitan telah ditentukan bahwa setiap kreditor pemegang hak tanggungan yang berkedudukan sebagai kreditor separatis dan memiliki hak preferen, dapat mengeksekusi haknya seolaholah tidak terjadi kepilitan, kecuali dalam hal penagihan suatu piutang sebagaimana dimaksud dalam Pasal 136 dan 137 Undang-Undang Kepailitan.

Hak kreditor pemegang hak tanggungan untuk mengeksekusi harta debitor pailit yang menjadi jaminan, seolah-olah tidak terjadi kepailitan, harus memperhatikan Pasal 56 ayat (1) Undang-Undang Kepailitan, sebelum kreditor pemegang hak tanggungan tersebut mengekseskusi atau menjualnya.

Mengenai Penjelasan Pasal 56 ayat (1) tersebut yang tujuannya bahwapenangguhan dimaksudkan untuk memperbesar kemungkinan mengoptimalkanharta pailit adalah bertentangan dengan hak separatis dari Pasal 21 Undang-UndangHak Tanggungan, karena sesuai Pasal 21 Undang-Undang Hak Tanggungantersebut menentukan bahwa apabila pemberi Hak Tanggungan dinyatakan pailit,maka pemegang Hak Tanggungan tetap berwenang melakukan segala hak yangdiperolehnya menurut ketentuan Undang-Undang Hak Tanggungan (UUHT).

Penjelasan Pasal 56 ayat (1) tersebut terlihat jelas bahwa UndangUndang Kepailitan dan Penundaan Kewajiban Pembayaran Utang tidak 
konsisten, dimana di satu sisi ketentuan Pasal 55 ayat (1) nampaknyamengakui hak separatis dan kreditur preferen, tetapi disisi lain ketentuan Pasal56 ayat (3) justru mengingkari hak separatis itu karena menentukan bahwabarang yang dibebani dengan hak jaminan (Hak Tanggungan) merupakan hartapailit Artinya bahwa Undang-Undang Kepailitan tidak memisahkan benda-bendayang dibebani Hak Jaminan sebagai benda-benda bukan rnerupakanharta pailit.

Pasal 57 ayat (1) Undang-Undang Kepailitan juga berlaku bagi kreditor pemegang Hak Tanggungan, yang mengatur mengenai jangka waktuu penangguhan yang berakhir demi hukum apabila kepailitan diakhiri lebih cepat atau pada saat dimulainya keadaan insolvensi.

Akibat hukum insolvensi antara lain adalah harta pailit segera dieksekusi dan dibagi, kecuali ada pertimbangan tertentu ( misalnya pertimbangan bisnis ). Dua bulan sejak dimulainya masa insolvensi, kreditor Pemegang Hak Tanggungan mempunyai hak untuk mengeksekusi objek hak tanggungan, sebagaimana yang diatur dalam Pasal 59 ayat (1) Undang-Undang Kepailitan. Kreditor Pemegang hak tanggungan yang melaksanakan haknya wajib memberikan pertanggungjawaban kepada kurator tentang hasil penjualan benda yang menjadi agunan tersebut dan menyerahkan sisa hasil penjualan setelah dikurangi jumlah utang, bunga, dan biaya kepada kurator. Dengan demikian apabila setelah debitur sudah dinyatakaninsolvensi, maka terhitung sejak hari itu juga kreditur pemegang hak tanggunganharus dapat rnenjual obyek hak tanggungan dengan tata cara sebagaimana yangditentukan oleh Pasal 20 Undang-Undang No. 4 Tahun 1996 tentang HakTanggungan jo. Pasal 60 Undang-undang No. 37 Tahun 2004 tentang Kepailitan dan Penundaan Kewajiban Pembayaran Utang.

Dalam jangka waktu lebih dari dua bulan sejak dimulainya keadaan insolvensi, kreditor pemegang hak tanggungan tidak melaksanakan haknya, maka kurator harus menuntut diserahkannya benda yang menjadi agunan dan selanjutnya dijual sesuai dengan cara sebagaimana yang dimaksud dalam Pasal 184 dan Pasal 185 Undang-Undang 
Kepailitan, tanpa mengurangi hak kreditor pemegang hak tanggungan atas hasil penjualan agunan ( objek hak tanggungan ) tersebut.

Kedudukan kreditor pemegang hak tanggungan dalam hal debitor dinyatakan pailit, tetap sebagai kreditor sparatis yang memilki hak preferen dan dapat melaksanakan hak eksekusinya meskipun harus menunggu masa penangguhan eksekusi selama 90 ( Sembilan puluh ) hari, atau jika debitor dinyatakan dalam keadaan insolvensi, maka kreditor pemegang hak tanggungan dapat melaksanakan hak eksekusinya paling lambat 2 bukan sejak dimulainya keadaan insolvensi.

Pasal 60 ayat (3) Undang-Undang Kepailitan juga mengatur bahwa apabila hasil penjualan objek hak tanggungan tersebut tidak mencukupi untuk melunasi piutangnya, maka kreditor pemegang hak tanggungan dapat mengajukan tagihan pelunasan atas kekurangan tersebut dari harta pailit sebagai kreditor konkuren, setelah mengajukan permintaan pencocokan piutang. Dalam keadaan ini Kedudukan kreditor pemegang hak tanggungan sebagai kreditor sparatis berubah menjadi kreditor konkuren dan memilki kedudukan yang sama seperti kreditor-kreditor lainnya dalam pelunasan utang debitor, dihitung berdasarkan besarnya piutang masing-masing dibandingkan terhadap piutang mereka secara keseluruhan, terhadap kekayaan debitor.

Dapat disimpulkan bahwa penjelasan Pasal 56 ayat (1) tersebut terlihat jelas adanya tidak ada konsistensi, dimana di satu sisi ketentuan Pasal 55 ayat (1) nampaknyamengakui hak separatis dan kreditur preferen, tetapi disisi lain ketentuanPasal 56 ayat (3) justru mengingkari hak separatis itu karenamenentukan bahwa barang yang dibebani dengan hak jaminan (HakTanggungan) merupakan harta pailit Artinya bahwa Undang-UndangKepailitan tidak memisahkan benda-benda yang dibebani Hak Jaminansebagai benda-benda bukan rnerupakan harta pailit.

\section{PENUTUP}




\section{Kesimpulan}

a. Hambatan dalam Pelaksanaan eksekusi hak tanggungan dalam hal debitor dinyatakan pailit, antara lain adalah:pertama,Debitor pailit tidak kooperatif sejak awal dimulainya proses kepailitan seperti sulit dimintai data tentang assetnya, tidak hadir dalam rapat pencocokan piutang, dan sulit untuk ditemui atau tidak bersedia hadir di pengadilan; Kedua, debitor beritikad buruk, seperti mengalihkan asset yang menjadi objek hak tanggungan, kepada pihak lain, sebelum dinyatakan pailit; Ketiga,Kurangnya tenggang waktu bagi kreditor Pemegang hak tanggungan untuk melaksanakan hak ekskusi atas objek hak tanggungan. Hal ini karena Waktu 2 ( dua ) bulan setelah keadaan insolvensi, merupakan waktu yang terlalu singkat bagi kreditor pemegang hak tanggungan untuk melaksanakan haknya sebagai kreditor sparatis yang mempunyai hak preferen; Keempat,Setelah kreditor pemegang hak tanggungan tidak melaksanakan haknya, maka kewenangan berada ditangan kurator, dalam beberapa kasus sering terjadi persekongkolan antara debitor yang beritikad buruk dengan kurator dalam pemberesan harta pailit, meskipun hal ini sulit untuk dibuktikan. Dan kelima,Ketidakprofesionalnya kurator dalam mengurus harta-harta debitor yang telah dinyatakan pailit, khususnya yang berkaitan dengan audit pembukuan.

b. Akibat hukum Putusan pailit terhadap kreditor preferen pemegang hak tanggungan, antara lain Akibat kepailitan bagi pemegang hak tanggungan sebagaiamana yang diatur dalam Undang-Undang Hak Tanggungan Penjelasan Pasal 21 yang menyatakan bahwa kedudukan diutamakan pemegang hak tanggungan dengan mengecualikan berlakunya akibat kepailitan pemberi hak tanggungan terhadap objek hak tanggungan. Pasal 55 Undang-Undang Kepailitan telah ditentukan bahwa setiap kreditor pemegang hak tanggungan yang berkedudukan sebagai kreditor separatis dan memiliki hak preferen, dapat mengeksekusi haknya seolah-olah tidak terjadi kepailitan, harus 
memperhatikan Pasal 56 ayat (1) Undang-Undang Kepailitan, sebelum kreditor pemegang hak tanggungan tersebut mengekseskusi atau menjualnya.

\section{Saran}

1. Pemerintah perlu melakukan revisi terhadap Undang-Undang No. 37 Tahun 2004 Kepailitan dan Penundaan Kewajiban Pembayaran Utang, pada Pasal 55 ayat (1) Undang-Undang Kepailitan dan Penundaan Kewajiban Pembayaran Utang, dapat menimbulkan multitafsir, hal ini akan menimbulkan menimbulkan ketidakpastian hukum. Untuk itu disarankan untuk mengganti dengan kata yang lebih tegas, atau menghilangkan kata "Seolaholah" dalam menghindari adanya ketidak pastian hukum bagi Hakim yang akan memutuskan maupun bagi kreditor khususnya kreditor pemegang hak tanggungan.

2. Perlu adanya penyempurnaan Undang-Undang No. 37 Tahun 2004 Undang-Undang Kepailitan dan Penundaan Kewajiban Pembayaran Utang, khususnya Pasal 56 ayat (1) untuk kata "ditangguhkan selama 90 hari”. Sebaiknya tidak perlu ada kata-kata ditangguhkan untuk menghindari terjadinya konflik norma, khususnya antara Undang-Undang Kepailitan dan Penundaan Kewajiban Pembayaran Utang dengan Undang-Undang Hak Tanggungan, yang nantinya dapat menimbulkan ketidakpastianHukum. 


\section{DAFTAR PUSTAKA}

Man S.Sastrawidjaja, Hukum Kepailitan dan Penundaan Kewajiban Pembayaran Utang, Bandung:PT.Alumni , 2006

Munir Fuady, Hukum Pailit, Bandung:PT. Citra Aditya Bakti, 2005

Ahmad Yani dan Gunawan Widjaja, Kepailitan, Jakarta:PT. Raja Grafindo Persada, 1999

Soerjono Soekanto dan Sri Mamudji. Penelitian Hukum Normatif (Suatu Tinjauan Singkat). Jakarta: Rajawali Pers, 2010.

Sugiyono, Metode Penelitian Kuantitatif, Kualitatif dan R\&D, Bandung: CV.Alfabeta, 2008,

Soerjono Soekanto, Pengantar Penelitian Hukum , Jakarta:UI Press, 1986,

Munir Fuady, Hukum Pailit Dalam Teori dan Praktek, Bandung:PT.Citra Aditya Bakti , 1999.

Ira Setiawati, wawancara, Hakim Pengadilan Niaga Semarang, Pada Tanggal 14 November 2013. 